\title{
Biodegradation of binary mixtures of octane with benzene, toluene, ethylbenzene or xylene (BTEX): insights on the potential of Burkholderia, Ralstonia, Pseudomonas, and Cupriavidus isolates
}

\section{Hernando P. Bacosa}

Mindanao State University - Iligan Institute of Technology: MSU-lligan Institute of Technology

Jhonamie Abiner Mabuhay-Omar ( $\sim$ jhonamie@gmail.com )

Western Philippines University https://orcid.org/0000-0002-8384-4449

Rodulf Anthony T. Balisco

Western Philippines University

Dawin M. Omar Jr.

Palawan State University

Chihiro Inoue

Tohoku University: Tohoku Daigaku

\section{Research Article}

Keywords: biodegradation, BTEX, octane, Burkholderia, binary mixture, hydrocarbons

Posted Date: March 19th, 2021

DOI: https://doi.org/10.21203/rs.3.rs-323650/v1

License: (c) (1) This work is licensed under a Creative Commons Attribution 4.0 International License.

Read Full License 


\section{Abstract}

The contamination of the environment by crude oil and its by-products, which mainly composed of aliphatic and aromatic hydrocarbons, is a widespread problem. Biodegradation by bacteria is one of the processes responsible for the removal of these pollutants. This study was conducted to determine the abilities of Burkholderia sp. B5, Ralstonia sp. B1, Pseudomonas sp. T1, and Cupriavidus sp. X5 to degrade binary mixtures of octane (representing aliphatic hydrocarbons) with benzene, toluene, ethylbenzene, or xylene (BTEX as aromatic hydrocarbons) at a final concentration of $100 \mathrm{ppm}$ under aerobic conditions. These strains were isolated from an enriched bacterial consortium (Yabase or $Y$ consortium) that prefer to degrade aromatic hydrocarbon over aliphatic hydrocarbons. We found that B5 degraded all BTEX compounds more rapidly than octane. In contrast, B1, T1 and X5 utilized more of octane over BTX compounds. B5 also preferred to use benzene over octane with varying concentrations of up to $200 \mathrm{mg} / \mathrm{l}$. B5 possesses alkane hydroxylase (alkB) and catechol 2,3-dioxygenase (C23D) genes, which are responsible for the degradation of alkanes and aromatic hydrocarbons, respectively. This study strongly supports our notion that Burkholderia played a key role in the preferential degradation of aromatic hydrocarbons over aliphatic hydrocarbons in the previously characterized $Y$ consortium. The preferential degradation of more toxic aromatic hydrocarbons over aliphatics is crucial in risk-based bioremediation.

\section{Introduction}

Petroleum hydrocarbons are among the widely reported contaminants of surface, groundwater, and marine environments (McGenity et al. 2012; Murphy et al. 2016). These compounds pose health hazards to humans and other ecological receptors. Many aromatic hydrocarbons such as benzene, toluene, ethylbenzene and xylene (collectively known as BTEX) and polycyclic aromatic hydrocarbons (PAHs) are known to have carcinogenic, neurotoxic and mutagenic potentials (Samanta et al. 2002; Haritash and Kaushik 2009; Masekameni et al. 2019). Another groups of hydrocarbons, the aliphatic hydrocarbons, which composed of straight chain, branched and cycloalkanes are usually more abundant in oil, but relatively less toxic compared to aromatic hydrocarbons (Potter and Simons 1998; Bacosa et al. 2010). The differences in the toxicities of these groups of hydrocarbons have attracted attention towards a riskbased remediation of hydrocarbon contaminated environments.

In polluted sites, hydrocarbons undergo biodegradation by actions of natural bacterial populations capable of utilizing these compounds as carbon and energy sources (Bacosa et al. 2016; Adzigbli et al. 2018; Dominguez et al. 2019; Bacosa et al. 2020). Upon the introduction of hydrocarbons, the natural microflora shifts to favor the growth of oil-degrading bacterial populations and often result in a significant shift in community structure (Severin et al. 2016; Gemmell et al. 2018; Bacosa et al. 2018; Kamalanathan et al. 2019; Steichen et al. 2020). The ability of the bacterial community to degrade the hydrocarbons is affected by various factors that include the type of bacteria, nutrients, sunlight, temperature, shoreline energy, and oil concentration (Bacosa et al. 2015; Gemmell et al. 2016; Liu et al. 2017; Evans et al. 2017; Williams et al. 2017; Sun et al. 2018; Bacosa et al. 2021). The biodegradation of 
oil is a sequential process in which the aliphatic hydrocarbons are generally degraded faster over aromatic hydrocarbons (Greenwood et al. 2008). However, the interest in bacteria that utilize aromatic hydrocarbons faster that aromatic hydrocarbons has received great interest in the past decade in an attempt to achieve a low-cost and more effective remediation of contaminated sites (Bacosa et al. 2010). Despite the many research studies conducted on the bacterial biodegradation of BTEX components, most studies have focused on the biodegradation of only one or two components per bacterial isolate (Singh et al. 2020).

We obtained a bacterial consortium through enrichment culturing from Yabase oil field in Akita, Japan (called "Y" consortium) that preferred to degrade aromatic hydrocarbons over aliphatic hydrocarbons (Bacosa et al. 2010). This consortium is mainly composed of bacteria closely related to Achromobacter, Alcaligenes, Cupriavidus, Achromobacter, and Rhodanobacter. Real-time polymerase chain reaction (PCR) analysis using primers targeting these bacterial groups revealed that Burkholderia increased with the degradation of xylene, a representative aromatic hydrocarbon in a binary mixture with decane (Bacosa et al. 2011). However, Cupriavidus was strongly associated with the disappearance of decane as a representative aliphatic hydrocarbon. In this study, we aimed to isolate representatives from these genera to investigate their respective potential to degrade aromatic and aliphatic hydrocarbons. Specifically, we were interested in isolating Burkholderia to determine its abilities to degrade binary mixtures of aliphatic and aromatic hydrocarbons.

\section{Materials And Methods Bacterial isolation}

The bacterial strains used in this study were isolated from the bacterial consortium obtained from Yabase oil field in Akita, Japan, called " $Y$ " consortium that preferentially degrade aromatic hydrocarbons over aliphatic hydrocarbons in kerosene as described in Bacosa et al. (2010) and Bacosa et al. (2011). Isolates were obtained through a serial dilution of bacterial suspension from the enrichment culture and plated in petri plates containing Bushnell Haas Medium (BHM), 1.5\% agarose, and $20 \mu \mathrm{l}$ of kerosene as the sole carbon and energy source (Bacosa et al. 2013; Bacosa and Inoue 2020). The plates were incubated for two weeks at $30^{\circ} \mathrm{C}$. Colonies with unique morphological characteristics were selected and purified by subsequent plating. Purified isolates were then cultured in test tubes containing BHM with $1 \%(\mathrm{v} / \mathrm{v})$ kerosene incubated at $30^{\circ} \mathrm{C}$ with shaking.

\section{Identification of bacterial isolates}

The isolates were identified by sequencing a fragment of 16S rRNA gene following the previously established protocol (Bacosa et al. 2010; Bacosa and Inoue 2020). Briefly, the cells were pelleted by centrifugation and total genomic DNA was extracted using Proteinase K, TTNE buffer, and TE saturated phenol. The almost full-length fragment of $16 \mathrm{~S}$ rRNA gene was amplified using universal primers $10 \mathrm{~F}$ and 1500R (Takami et al. 1999). After confirmation of the desired PCR product by gel electrophoresis, the PCR products were purified using Gene Elute Mammalian Total RNA Miniprep Kit (Sigma Aldrich) according to 
the manufacturer's protocol. The purified DNA was then sequenced following the Big Dye Terminator v3.1 Cycle sequencing chemistry in Applied Biosystems Genetic Analyzer 3130 (Bacosa et al. 2013;

Dominguez et al. 2019; Bacosa and Inoue 2020). The isolates were preliminarily sequenced using primer $10 \mathrm{~F}$. To sequence a nearly full length $16 \mathrm{~S}$ rRNA gene fragment, representative strains were sequenced using primers 907R and 1500R. DNA sequences were assembled by Genetyx software and compared to the sequences in the GenBank. The sequences were submitted to the GenBank under Accession Numbers AY741343, AB109778, EF424401, AB266610.

\section{Detection of alkane-degrading and aromatic-degrading genes in B5 isolate}

The 238-bp fragment of catechol 2,3-dioxygenase gene (C23D) was amplified using primers 23CAT-F and 23CAT-R developed by Mesarch et al. (2000) following the PCR amplification conditions therein. C23D is a common pat for the degradation of aromatic hydrocarbons. A fragment ( $100 \mathrm{bp})$ of alkane hydroxylase gene (alkB), which is responsible for the terminal oxidation of alkane was amplified using primers AlkB-F and AlkB-R by Powell et al. (2006) following established conditions.

\section{Biodegradation experiment}

The biodegradation experiment was conducted to determine which isolate would degrade aromatic hydrocarbons faster than aliphatic hydrocarbons under aerobic conditions. We used our established procedure on binary mixture of aliphatic and aromatic hydrocarbons (Bacosa et al. 2011). To accomplish this, the isolates were precultured in BHM medium with kerosene until reaching the late exponential phase of growth (Bacosa et al. 2010). The cells were then harvested by centrifugation, washed twice with phosphate saline buffer, and resuspended in BHM. Cell suspension $(0.5 \mathrm{~mL})$ was inoculated in $120-\mathrm{ml}$ sterile serum vial containing $9.5 \mathrm{ml}$ of BHM. The bacterial cells were added to attain an initial density of $\sim 1 \times 10^{7}$ cell per $\mathrm{ml}$ (Bacosa et al. 2011). The vial was then capped with Teflon-line septum and sealed with an aluminum cap. $n$-Octane, benzene, toluene, ethylbenzene, and $p$-xylene were individually spiked into the vials using a microsyringe at a final concentration of $100 \mathrm{mg} / \mathrm{l}$. Each vial contains $n$-octane or any of the BTEX compound in what is termed as a binary mixture representing an aliphatic and an aromatic hydrocarbon compound. All hydrocarbons used have purities of $>99 \%$ and obtained from Wako Pure Chemicals (Osaka, Japan). The following were the sets of binary mixture prepared for the isolates: octane-benzene, octane-toluene, octane-ethylbenzene, and octane-xylene. Three replicate vials were prepared for each treatment, wherein vials were placed in an orbital shaker and incubated at $30^{\circ} \mathrm{C}$ with shaking at $120 \mathrm{rpm}$. Control vials were not prepared in this experiment because our previous work showed no appreciable change in concentration in the uninoculated sealed vials (Bacosa et al. 2011; Bacosa et al. 2012).

Burkholderia sp.was further evaluated for the degradation of binary mixture of octane and benzene with varying initial concentrations. Benzene was chosen among the BTEX compounds because it has no substituted methyl or alkyl group that provides for alternate sites for initial oxidation of the aromatic ring. The concentrations tested were $100 \mathrm{mg} / \mathrm{l}$ octane-100 mg/l benzene, $100 \mathrm{mg} / \mathrm{l}$ octane-200 mg/l benzene, 
and $200 \mathrm{mg} / \mathrm{l}$ octane-200 $\mathrm{mg} / \mathrm{l}$ benzene. Another treatment was prepared for the degradation of a mixture of octane, benzene, and toluene at a final concentration of $100 \mathrm{mg} / \mathrm{l}$. The experimental procedure was prepared using a new inoculum. Control vials with no microbial inoculants were prepared to account for the loss of hydrocarbons in this set of experiment.

\section{Hydrocarbon analysis}

The vials were analyzed periodically for the residual hydrocarbon compounds using headspace gas chromatography as previously described (Bacosa et al. 2011; Bacosa et al. 2012). Briefly, headspace (50 $\mu \mathrm{l})$ was withdrawn from the vial using a $250 \mu \mathrm{l}$ microsyringe (Hamilton, USA) and injected directly into a gas chromatograph (GC-4000, GL Sciences Inc., Japan) equipped with a flame ionization detector (FID). The column used was an Inert- Cap $17 \mathrm{MS}$ column (30 m long, $0.25 \mathrm{~mm}$ internal diameter, $0.25 \mu \mathrm{m}$ film thickness). The injector and detector temperatures were set at $350^{\circ} \mathrm{C}$. The column temperature was adjust based on the combination of hydrocarbons substrates and ranged between $80^{\circ} \mathrm{C}$ and $100^{\circ} \mathrm{C}$. Helium was used as a carrier gas at a flow rate of $1 \mathrm{ml} / \mathrm{min}$. The quantification of hydrocarbons was achieved by plotting against a seven-point standard curve prepared according to the combination of the hydrocarbon substrates.

\section{Growth in PAHs}

The growth of the four isolates in selected PAHs compounds, namely: fluorene, phenanthrene, anthracene, and pyrene (Wako, Osaka, Japan) was evaluated following established procedure Bacosa and Inoue 2020). Briefly, each isolate was incubated in $30 \mathrm{ml}$ test tube containing $10 \mathrm{ml}$ of BHM and $1000 \mathrm{mg} / \mathrm{l}$ of each PAH compound, for 14 days with shaking at $30^{\circ} \mathrm{C}$. The growth after 14 days of incubation was measured using spectrophotometer at an optical density of $600 \mathrm{~nm}$ and evaluated using standard criteria (Chaerun et al. 2004; Bacosa and Inoue 2020).

\section{Results}

Thirty bacterial strains were successfully isolated from the " $Y$ " consortium. Preliminary sequencing using primer $10 \mathrm{~F}$ revealed that these isolates were closely related to Burkholderia, Ralstonia, Pseudomonas and Cupriavidus. Among the isolates, four representative strains representing the identified genera were sequenced further using 907R and 1500R. These isolates are B5- closely related to Burkholderia cepacia ATCC 27515, B1-closely related to Ralstonia basilensis, T1- closely related to Pseudomonas panipatensis Esp1, and X5-closely related to Cupriavidus sp. KU-21 (Table 1). All of these isolates have similarities of greater than $99.5 \%$. Note that only Burkholderia and Cupriavidus were detected by clone library analysis in "Y" consortium (Bacosa et al., 2010).

All of the four isolates were tested in the degradation of binary mixture of octane with benzene, toluene, ethylbenzene or $p$-xylene. B5 degraded all BTEX compounds faster than octane (Fig. 1). It was observed that xylene was degraded the fastest (within 20 hours) while toluene the slowest (after $100 \mathrm{~h}$ ). The significant degradation of octane commenced when octane was nearly totally depleted. Although ethylbenzene was degraded a bit faster than octane in ethylbenzene-octane mixture, the degradation of 
these two compounds were closely similar. Isolates $\mathrm{B} 1, \mathrm{~T} 1$, and $\mathrm{X} 5$ showed a different pattern of action wherein octane was degraded faster than any of benzene, toluene and xylene. However, this is not the case in octane-ethylbenzene mixture, where octane and ethylbenzene were similarly degraded. Interestingly, isolates B1 hardly degraded toluene, while T1 and X5 was not able to utilize benzene even after prolonged incubation to $280 \mathrm{~h}$.

Another set of experiment was performed to evaluate the response of B5 in varying concentrations of octane and benzene. Benzene was remarkably degraded more rapidly than octane regardless of concentration of octane or benzene (Fig. 2). A concentration of $100 \mathrm{mg} / \mathrm{l}$ benzene was completely degraded within 40 hours even in the presence of $100 \mathrm{mg} / \mathrm{l}$ and $200 \mathrm{mg} / \mathrm{l}$ of octane. When added at higher concentration $(200 \mathrm{mg} / \mathrm{l})$, benzene degradation occurred longer such that complete degradation happened in $60 \mathrm{~h}$.

As shown in Fig. 3, isolate B5 harbors both C23D and alkB genes, which are associated with the oxidation of aromatic hydrocarbons and aliphatic hydrocarbons, respectively. When a mixture of three compounds was inoculated and incubated with B5, complete degradation of benzene happened in less than $40 \mathrm{~h}$, followed by toluene at $50 \mathrm{~h}$, and octane at $80 \mathrm{~h}$ (Fig. 2E). Moreover, B5 also showed good growth in representative PAHs such as fluorene, phenanthrene, anthracene, and pyrene suggesting its abilities to degrade these PAHs compounds (Table 2).

\section{Discussion}

Crude oil and its by products are highly complex mixtures composed of more toxic aromatic hydrocarbons and more abundant yet less harmful aliphatic hydrocarbons. Generally, aliphatic hydrocarbons are consumed faster than aromatics by microorganisms (Greenwood et al. 2008; Liu et al. 2017). The search for microbial consortium or bacterial strain capable of degrading the more toxic components in pollutant mixture such as hydrocarbons is important in risk-based remediation. Here, we demonstrated that a strain of Burkholderia consumed the more toxic aromatic hydrocarbons rapidly.

The source consortium ( $Y$ or Yabase consortium) was composed of a variety of bacteria including Achromobacter, Alcaligenes, Cupriavius, Burkholderia, Herbaspirillum, Paucimonas, Rhodanobacter, Pseudoxanthomonas, Epilithonimonas, and Terrimonas (Bacosa et al. 2010). However, among the 30 unique colonies obtained during isolation, only Burkholderia and Cupriavidus were identified. Ralstonia and Pseudomonas, which were not detected by clone library, were isolated. Isolation using kerosene on agar plate could have favored the colony formation of these bacteria. Possibly, the other bacteria identified using $16 \mathrm{~S}$ rRNA sequencing of clone library did not form colonies as more than $99 \%$ of microorganism are unculturable and cannot form colonies on agar plates (Nichols 2007).

Among all the isolates, B5 degraded all BTEX compounds faster than octane. Using primers designed to amplify the 16S rRNA genes, both Burkholderia and Cupriavidus increased with the degradation of $p$ xylene as revealed by real-time PCR (Bacosa et al. 2012). Here, we clearly demonstrated that the B5 isolate degrade $p$-xylene faster than octane when these compounds were added together in the same 
bottle. This strongly supports our claim that Burkholderia were the key aromatic degraders in $\mathrm{Y}$ consortium Burkholderia is one of those bacterial species, whether alone or in consortium, known to degrade BTEX compounds, heavy oil, and various aliphatic and aromatic hydrocarbons (Lee et al. 2012; Lee et al. 2019: Bacosa and Inoue 2020). In this study, it was observed that xylene was degraded the fastest while toluene the slowest. This contrasted with what was stated by El-Naas et al. (2014) that toluene is the most easily biodegradable among the BTEX compounds due to the presence of the substituent group on the ring that offers an alternative route of attack on the side chain or oxidize the aromatic ring.

There was a different pattern of biodegradation of isolates $\mathrm{B} 1, \mathrm{~T} 1$, and $\mathrm{X} 5$ wherein octane was degraded faster while octane and ethylbenzene were similarly degraded. Ethylbenzene degradation can take place by directly oxidizing the aromatic ring or acting on the ethyl group (Chakraborty et al. 2005). Likely, the isolates oxidized octane and ethyl side chain in ethylbenzene concurrently resulting in simultaneous degradation in the binary mixture. Benzene is known to be more recalcitrant than its alkylated derivatives toluene, ethylbenzene and xylene isomers because benzene molecule is thermodynamically stable due to the symmetric $\pi$-electron system of the aromatic ring and the lack of potentially destabilizing or reactive substituents (Vogt et al. 2011). Unlike TEX compounds with substituted alkyl side chains, benzene degradation can only proceed with the initial attack of the ring so degradation often proceeds very slowly (Heider 2007; Vogt et al. 2011)). Probably, the genes responsible for benzene degradation were repressed by the metabolite of octane or these two isolates do not have benzene-degrading genes at all (Juhasz et al. 2002; Hennessee and Li 2016). The unique capability of B5 isolate to oxidized aromatic hydrocarbons much faster than octane signifies its innate characteristics to consume aromatic hydrocarbons for growth (Lee et al. 2019).

When B5 was exposed to varying concentrations of octane and benzene, benzene was remarkably degraded more rapidly than octane and when added with higher concentration of benzene, degradation occurred longer. It is possible that at increasing concentration, the consequent initial phase lag time is also increasing (Musat and Widdel 2008; Laban et al. 2009). Note that octane was characterized by more than $20 \mathrm{~h}$ of lag phase and complete degradation occurred in 80 hours regardless of initial concentration. Doubling the benzene concentration did not result in the inhibition of aromatic-preferring potential of B5 and its degradation pattern suggesting that the genes for aromatic hydrocarbons of this bacterium are expressed, not repressed. The C23D gene, which is an important gene and pathway for aromatic hydrocarbons degradation, was observed in B5. The dioxygenases activate the aromatic nucleus by introducing molecular oxygen to yield phenol or cis-benzene dihydrodiol, compounds that are further oxidized to catechol (Gibson and Parales 2000; Tao et al. 2004). The aromatic ring of catechol is finally cleaved by further dioxygenases in ortho- or meta-position (Vaillancourt et al. 2006). Also, a fragment of alkB gene which is responsible for the initial attack on terminal carbon in the alkane chain was detected in B5. These two genes harbored by B5 could be expressed for the degradation of both octane and BTEX compounds during the incubation period. Moreover, the degradation potential of B5 is not just limited to BTEX. It also showed good growth in different PAH compounds suggesting that it contains PAH dioxygenase genes likely responsible for the attack of the ring in these more complex and more 
recalcitrant compounds. This is consistent with our observation with " $Y$ " consortium in which PAHs of up to 3-rings were preferentially degraded over alkanes (Bacosa et al. 2010)

Overall, the findings of the experiments presented here showed that Burkholderia sp.B5 has remarkable ability to preferentially degrade all BTEX compounds completely and much faster than octane. Even if the concentration of both benzene and octane varied and increased, the preferential degradation of benzene over octane occurred. B5 also exemplified good growth in fluorene, phenanthrene, anthracene and pyrene indicating their potential to degrade several PAHs compounds. B5 harbor alkane hydroxylase and C23D playing key roles in the oxidation of aliphatic and aromatic hydrocarbons, respectively. These sets of evidences support our previous findings that Burkholderia in the $Y$ consortium plays a crucial role in the preferential biodegradation of aromatic hydrocarbons over aliphatic hydrocarbons. Our results advance our understanding on the roles of aromatic-preferring bacteria towards a risk-based remediation. Bacteria that rapidly degrade the more toxic components of pollutant mixtures are useful in cost effective, efficient and successful bioremediation.

\section{Declarations}

\section{Acknowledgment}

Hernando Bacosa is grateful to the support from the Japanese Government Monbukagakusho Scholarship program to pursue graduate studies in Tohoku University.

\section{References}

Adzigbli L, Bacosa HP, Deng Y (2018) Response of microbial communities to oil spill in the Gulf of Mexico; A review. Afr J Microbiol Res 12(23): 536-545. https://doi.org/10.5897/AJMR2018.8843

Bacosa HP, Erdner D, Liu Z (2015) Differentiating the roles of photooxidation and biodegradation in the weathering of light louisiana sweet crude oil in surface water from the Deepwater Horizon site. Mar Pollut Bull 95: 265-272. https://doi.org/10.1016/j.marpolbul.2015.04.005

Bacosa HP, Erdner DL, Rosenheim B, Shetty P, Seitz K, Baker B, Liu, Z (2018) Hydrocarbon degradation and response of seafloor sediment bacterial community in the northern Gulf of Mexico to light Louisiana sweet crude oil. ISME J 12: 2532-2543. https://doi.org/1038/s41396-018-0190-1

Bacosa HP, Inoue C (2020) Heavy oil degrading Burkholderia and Pseudomonas strains: insights on the degradation potential of isolates and microbial consortia. Pal Sci 12: 74-89

Bacosa HP, Kang A, Lu K, Liu Z (2021). Initial oil concentration affects hydrocarbon biodegradation rates and bacterial community composition in seawater. Mar Pollut Bull 162: 111867.

https://doi.org/10.1016/j.marpolbul.2020.111867 
Bacosa HP, Suto K, Inoue C (2010) Preferential degradation of aromatic hydrocarbons in kerosene by a microbial consortium. Int Biodeterior Biodegradation 64: 702-710.

https://doi.org/10.1016/j.ibiod.2010.03.008

Bacosa HP, Suto K, Inoue C (2011) Preferential utilization of petroleum oil hydrocarbon components by microbial consortia reflects degradation pattern in aliphatic-aromatic hydrocarbon binary mixtures. World J Microbiol Biotechnol 27: 1109-1117. https://doi.org/10.1007/s11274-010-0557-6

Bacosa HP, Suto K, Inoue C (2012) Bacterial community dynamics during the preferential degradation of aromatic hydrocarbons by a microbial consortium. Int Biodeterior Biodegradation 74: 109-115. https://doi.org/10.1016/j.ibiod.2012.04.022

Bacosa HP, Suto K, Inoue C (2013) Degradation potential and microbial community structure of heavyoil enriched microbial consortia from mangrove sediments in Okinawa, Japan. J. Environ Sci Health A: Toxic/Hazardous Substances and Environmental Engineering 48: 835-846.

https://doi.org/10.1080/10934529.2013.761476

Bacosa HP, Thyng KM, Plunkett S, Erdner DL, Liu Z (2016) The tarballs on Texas beaches following the 2014 Texas City "Y" spill: modeling, chemical, and microbiological studies. Mar Pollut Bull 109: 236-244. https://doi.org/10.1016/j.marpolbul.2016.05.076

Bacosa HP, Steichen JM, Kamalanathan M, Windham R, Lubguban A, Labonte M, Kaiser K, Hala D, Santschi PH, Quigg AS (2020) Polycyclic aromatic hydrocarbons (PAHs) and putative PAH degrading bacteria in Galveston Bay, Texas (USA) following the 2017 Hurricane Harvey. Environ Sci Pollut Res 27: 34987-34999. https://doi.org/10.1371/journal.pone.0243734

Chaerun KS, Tazaki K, Asada R and Kogure K (2004) Bioremediation of coastal areas 5 years after the Nakhodka oil spill in the Sea of Japan: Isolation and characterization of hydrocarbon-degrading bacteria. Environ Int 30: 911-922. https://doi.org/10.1016/j.envint.2004.02.007

Chakraborty R, O'Connor SM, Chan E, Coates JD (2005). Anaerobic degradation of benzene, toluene, ethylbenzene, and xylene compounds by Dechloromonas strain RCB. Appl Environ Microbiol 71(12): 8649-8655. https://doi.org/10.1128/AEM.71.12.8649-8655.2005

Dominguez JJ, Bacosa HP, Chien MF, Inoue C (2019) Enhanced degradation of polycyclic aromatic hydrocarbons (PAHs) in the rhizosphere of sudangrass (Sorghum $\times$ drummondii). Chemosphere 234: 789-795. https://doi.org/10.1016/j.chemosphere.2019.05.290

El-Naas MH, Acio JA, El Telib AE (2014) Aerobic biodegradation of BTEX: Progresses and Prospects, J Environ Chem Engg 2 (2): 1104-1122. https://doi.org/10.1016/j.jece.2014.04.009

Evans M, Liu J, Bacosa H, Rosenheim BE Liu Z (2017) Petroleum hydrocarbon persistence following the Deepwater Horizon oil spill as a function of shoreline energy. Mar Pollut Bull 115: 47-56. 
https://doi.org/10.1016/j.marpolbul.2016.11.022

Gemmell B, Bacosa HP, Dickey B, Gemmell C, Alqasemi L, Buskey E (2018) Rapid alterations to marine microbiota communities following an oil spill. Ecotoxicology 27: 505-515.

https://doi.org/10.1007/s10646-018-1923-7

Gemmell B, Bacosa HP, Liu Z, Buskey, EJ (2016) Can gelatinous zooplankton influence the fate of crude oil in marine environments? Mar Pollut Bull 113: 483-487.

https://doi.org/10.1016/j.marpolbul.2016.08.065

Gibson DT, Parales RE (2000) Aromatic hydrocarbon dioxygenases in environmental biotechnology. Curr Opin Biotechnol 11: 236-243. https://doi.org/10.1016/S0958-1669(00)00090-2

Greenwood PF, Wibrow S, George SJ, Tibbett M (2008) Sequential hydrocarbon biodegradation in a soil from arid coastal Australia, treated with oil under laboratory controlled conditions. Org Geochem 39:

1336e1346. https://doi.org/10.1016/j.orggeochem.2008.05.005

Haritash AK, Kaushik CP (2009) Biodegradation aspects of polycyclic aromatic hydrocarbons (PAHs): a review. J Hazard Mater 169: 1-15. https://doi.org/10.1016/j.jhazmat.2009.03.137

Heider J (2007) Adding handles to unhandy substrates: anaerobic hydrocarbon activation mechanisms. Curr Opin Chem Biol 11(2):188-94. https://doi.org/10.1016/j.cbpa.2007.02.027

Hennessee CT, Li QX (2016). Effects of polycyclic aromatic hydrocarbon mixtures on degradation, gene expression, and metabolite production in four Mycobacterium species. Appl Environ Microbiol 82: 33573369. https://doi.org/10.1128/AEM.00100-16

Juhasz AL, Stanley GA, Britz ML (2002) Metabolite repression inhibits degradation of benzo[a]pyrene and dibenz[a, h]anthracene by Stenotrophomonas maltophila VUN 10, 003. J Ind Microbiol Biotechnol 28:8896. http://doi.org/10.1038/sj/jim/7000216

Kamalanathan M, Chiu MH, Bacosa HP, Schwehr K, Tsai SM, Doyle S, Yard A, Mapes S, Vasquez C, Bretherton L, Sylvan JB, Santschi P, Chin WC Quigg A (2019) Role of polysaccharides in diatom Thalassiosira pseudonana and its associated bacteria in hydrocarbon presence. Plant Physiol 180 (4): 1898-1911. https://doi.org/10.1104/pp.19.00301

Laban NA, Selesi D, Jobelius C, Meckenstock RU (2009) Anaerobic benzene degradation by Gram-positive sulfate-reducing bacteria. FEMS Microbiol Ecol 68:300-311 https://doi.org/10.1111/j.1574$6941.2009 .00672 . x$

Lee Y, Lee Y, Jeon CO (2019) Biodegradation of naphthalene, BTEX, and aliphatic hydrocarbons by Paraburkholderia aromaticivorans BN5 isolated from petroleum-contaminated soil. Sci Rep 9: 860. https://doi.org/10.1038/s41598-018-36165-x 
Lee SH, Jin HM, Lee HJ, Kim JM, Jeon CO (2012) Complete genome sequence of the BTEX-degrading bacterium Pseudoxanthomonas spadix BD-a59. J Bacteriol 194 (2):544.

https://doi.org/10.1128/JB.06436-11

Liu J, Bacosa HP, Liu Z (2017) Potential environmental factors affecting oil-degrading bacterial populations in deep and surface waters of the northern Gulf of Mexico. Front Microbiol 7: 2131. https://doi.org/10.3389/fmicb.2016.02131

Masekameni MD, Moolla R, Gulumian M, Brouwer D (2019) Risk Assessment of Benzene, Toluene, Ethyl Benzene, and Xylene Concentrations from the Combustion of Coal in a Controlled Laboratory Environment. Int J Environ Res Public Health 16(1):95. https://doi.org/10.3390/ijerph16010095

McGenity TJ, Folwell BD, McKew BA, Sanni GO (2012) Marine crude-oil biodegradation: a central role for interspecies interactions. Aquat Biosyst 8: 1-19. https://doi.org10.1186/2046-9063-8-10

Mesarch MB, Nakatsu CH, Nies L (2000) Development of Catechol 2,3-Dioxygenase-Specific Primers for Monitoring Bioremediation by Competitive Quantitative PCR. Appl Environ Microbiol 66 (2): 678-683. https://doi.org/10.1128/AEM.66.2.678-683.2000

Murphy D, Gemmell B, Vaccarri L, Li C, Bacosa HP, Evans M, Gemmell C, Harvey T, Jalali M, Niepa T (2016) An in-depth survey of the oil spill literature since 1968: Long term trends and changes since Deepwater Horizon. Mar Pollut Bull 113: 371-379. https://doi.org/10.1016/j.marpolbul.2016.10.028

Musat F, Widdel F (2008) Anaerobic degradation of benzene by a marine sulfate-reducing enrichment culture, and cell hybridization of the dominant phylotype. Environ Microbiol 10:10-19.

Nichols D (2007) Cultivation gives context to the microbial ecologist. FEMS Microbiol Ecol. 60(3):351357. https://doi.org/10.1111/j.1574-6941.2007.00332.x.

Potter TL, Simmons KE (1998) Composition of petroleum mixtures. In: Total petroleum hydrocarbon criteria working group series, Vol. 2. Amherst Scientific Publishers, Amherst, MA, 75-80. https://doi.org/10.1111/j.1462-2920.2007.01425.x

Powell SM, Ferguson SH, Bowman JP, Snape I (2006) Using real-time PCR to assess changes in the hydrocarbon-degrading microbial community in Antarctic soil during bioremediation. Microb Ecol 52: 523-532. https://doi.org/10.1007/s00248-006-9131-z

Samanta SK, Singh OV, Jain RK (2002) Polycyclic aromatic hydrocarbons: environmental pollution and bioremediation. Trends Biotechnol 20: 243-248. https://doi.org/10.1016/S0167-7799(02)01943-1

Severin T, Bacosa HP, Sato A, Erdner DL (2016) Dynamics of Heterocapsa sp. and the associated attached and free-living bacteria under the influence of dispersed and undispersed crude oil. Lett Appl Microbiol 63: 419-425. https://doi.org/10.1111/lam.12661 
Steichen JL, Labonté JM, Windham R, Hala D, Kaiser K, Setta S, Faulkner PC, Bacosa HP, Yan G, Kamalanathan M, Quigg A (2020). Microbial, physical, and chemical changes in Galveston Bay following an extreme flooding event, Hurricane Harvey. Front Mar. Sci 7: 186.

https://doi.org/10.3389/fmars.2020.00186

Singh P, Singh VP, Singh R, Borthakur A, Madhav S, Ahamad A, Kumar A, Pal DB, Tiwary D, Mishra PK (2020) Chapter 1 - Bioremediation: a sustainable approach for management of environmental contaminants. In: Singh P, Kumar A, Borthakur A (ed), Abatement of Environmental Pollutants, Elsevier, pp 1-23. https://doi.org/10.1016/B978-0-12-818095-2.00001-1

Sun L, Chiu M, Xu C, Lin P, Schwehr K, Bacosa HP, Kamalanathan M, Quigg A, Chin W, Santschi P (2018) The effects of sunlight on the composition of exopolymeric substances and subsequent aggregate formation during oil spills. Mar Chem 203: 49-54. https://doi.org/10.1016/j.marchem.2018.04.006

Tao Y, Fishman A, Bentley WE and Wood TK (2004) Altering toluene 4-monooxygenase by active-site engineering for thesynthesis of 3-methoxycatechol, methoxyhydroquinone, andmethylhydroquinone. J Bacteriol 186: 4705-471. https://doi.org/10.1128/JB.186.14.4705-4713.2004

Takami H, Kobata K, Nagahama T, Kobayashi H, Inoue A, Horikoshi K (1999) Biodiversity in deep-sea sites located near the south part of Japan. Extremophiles 3: 97-102. https://doi.org/10.1007/s007920050104

Vaillancourt FH, Bolin JT, Eltis LH (2006) The ins and outs of ring-cleaving dioxygenases. Crit Rev Biochem Mol Biol 41: 241-267 https://doi.org/10.1080/10409230600817422

Vogt C, Kleinsteuber S, Richnow HH (2011) Anaerobic benzene degradation by bacteria. Microb Biotechnol 4(6): 710-724. https://doi.org/10.1111/j.1751-7915.2011.00260.x

Williams K, Bacosa HP, Quigg A (2017) The impact of dissolved inorganic nitrogen and phosphorous on responses of microbial plankton to the Texas City "Y" oil spill in Galveston Bay, Texas (USA). Mar Pollut Bull 121: 32-44. https://doi.org/10.1016/j.marpolbul.2017.05.033

\section{Tables}

Due to technical limitations, table 1, 2 is only available as a download in the Supplemental Files section.

\section{Figures}



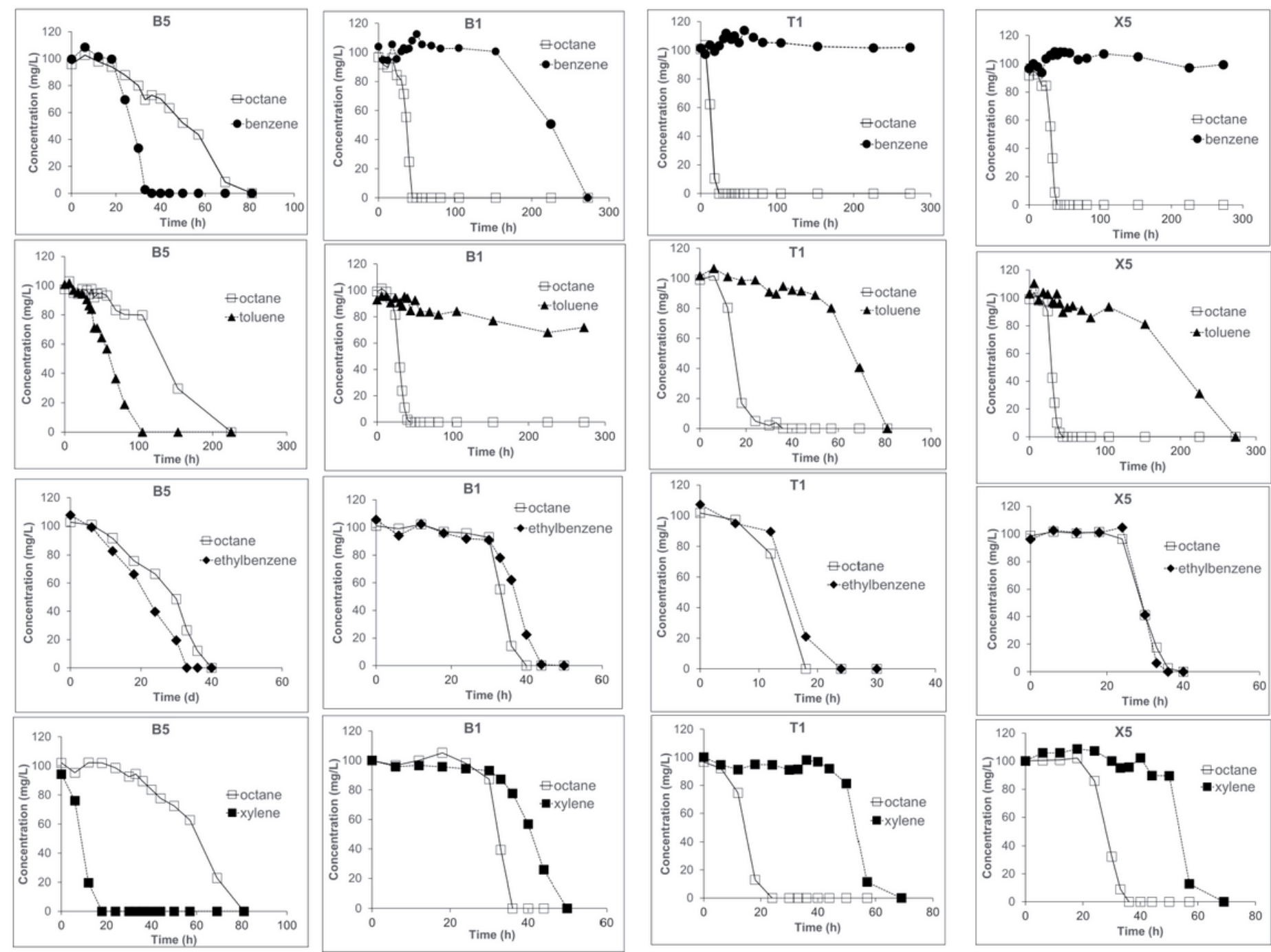

\section{Figure 1}

Degradation of the binary mixtures of octane with benzene, toluene, ethylbenzene or xylene by Burkholderia sp. B5, Ralstonia sp. B1, Pseudomonas sp. T1 and Cupriavidus sp. X5 

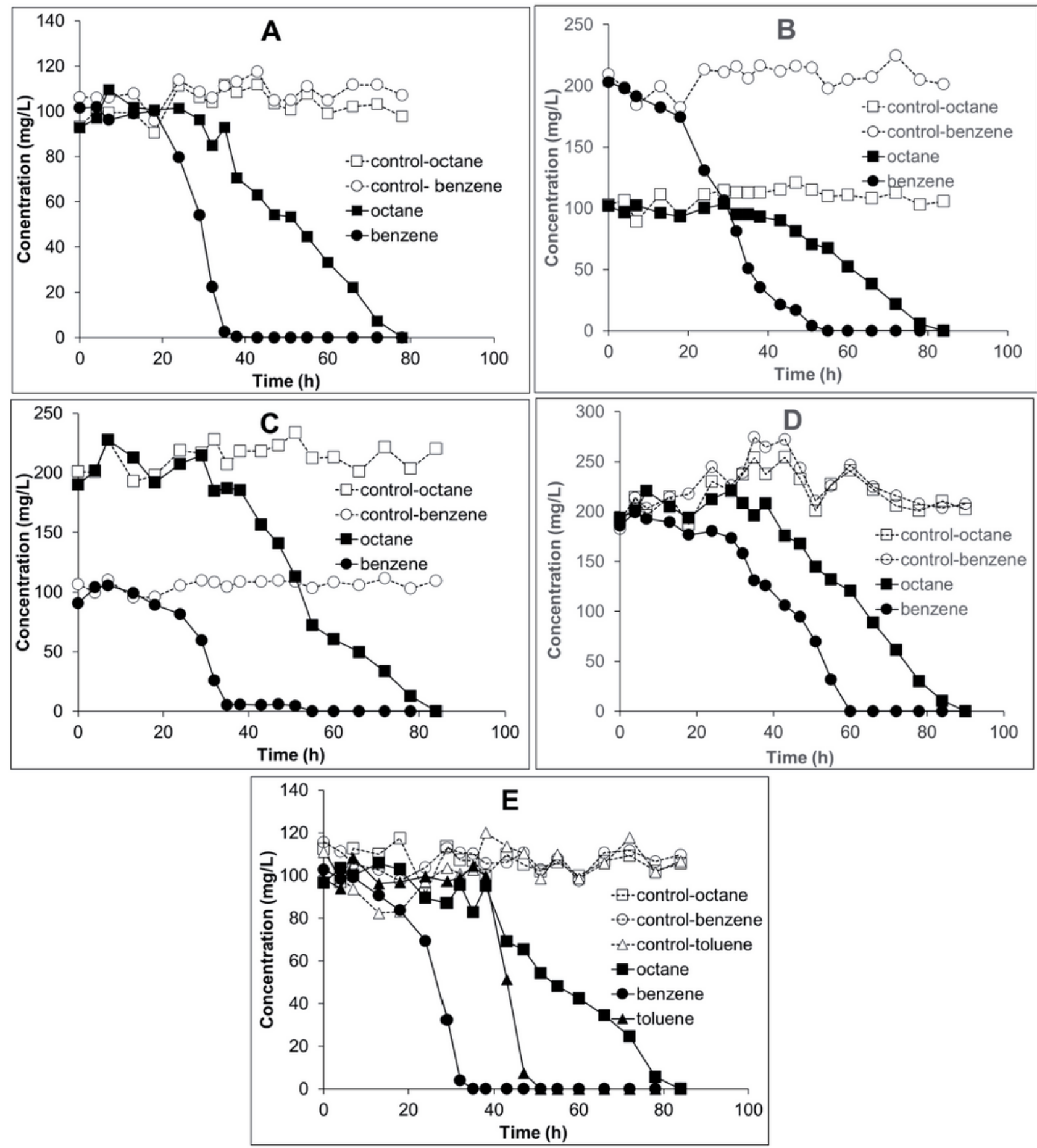

\section{Figure 2}

Degradation of binary mixtures of different concentration of octane and benzene by Burkholderia sp. B5 (a) $100 \mathrm{mg} / \mathrm{L}$ octane and $100 \mathrm{mg} / \mathrm{L}$ benzene, (b) $100 \mathrm{mg} / \mathrm{L}$ octane and $200 \mathrm{mg} / \mathrm{L}$ benzene, (c) $100 \mathrm{mg} / \mathrm{L}$ octane and $200 \mathrm{mg} / \mathrm{L}$ benzene, (d) $200 \mathrm{mg} / \mathrm{L}$ octane and $200 \mathrm{mg} / \mathrm{L}$ benzene, (e) $100 \mathrm{mg} / \mathrm{L}$ each of octane, benzene, and toluene 


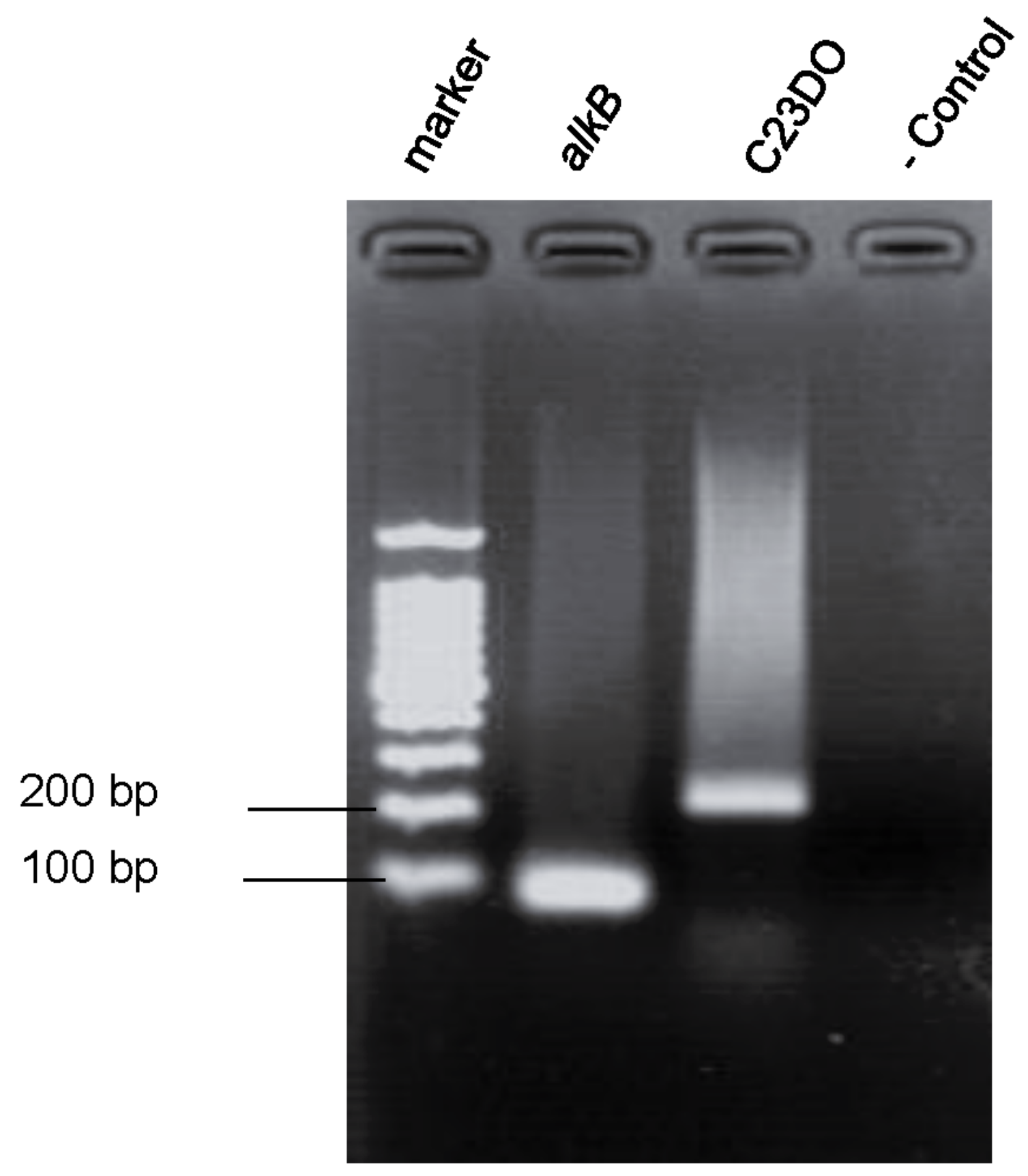

Figure 3

Detection of alkane hydroxylase (alkB) and catechol 2,3-dioxygenase genes in Burkholderia sp. B5

\section{Supplementary Files}

This is a list of supplementary files associated with this preprint. Click to download. 
- Tables.pdf

Page 16/16 